\title{
MAUTE GROUP DAN JARINGAN KELUARGA DALAM KELOMPOK ISLAM RADIKAL DI FILIPINA SELATAN
}

\author{
Putu Agung Nara Indra Prima Satya \\ Program Studi Ilmu Hubungan Internasional \\ Fakultas Ilmu Sosial dan Ilmu Politik \\ Universitas Katolik Parahyangan \\ narasatya.prima@gmail.com
}

\begin{abstract}
Abstrak
Perjalanan konflik antara pemerintah Filipina dengan kelompok-kelompok separatis di Filipina Selatan memunculkan beragam kelompok militan Islam seperti MILF, Abu Sayyaf, dan yang paling mutakhir, Kelompok Maute. Banyaknya kelompok militan yang muncul tersebut berawal dari perpecahan-perpecahan di dalam kelompok-kelompok militan tradisional di Filipina Selatan khususnya MNLF dan MILF. Fenomena perpecahan ini akhirnya memunculkan kelompok-kelompok sempalan yang kerap terlibat pertempuran di antara mereka sendiri. Di sisi lain, kelompok-kelompok tersebut justru memiliki latar belakang ikatan keluarga yang sangat erat. Tulisan ini menyoroti tentang peranan jaringan keluarga di dalam keberadaan kelompok-kelompok militan di Filipina Selatan khususnya Kelompok Maute. Kelompok Maute dapat berkembang pesat karena pendiri dan sebagian besar anggotanya memiliki hubungan keluarga dengan kelompok Moro Islamic Liberation Front. Ikatan keluarga ini akhirnya menjadi pelindung sekaligus faktor penting bagi berkembangnya radikalisme Kelompok Maute.
\end{abstract}

Kata kunci: filipina selatan; kelompok radikal islam; MILF; kelompok maute; ikatan keluarga.

\begin{abstract}
The history of conflict between Philippines government and separatist group in Southern Phillipines area has formed many radical Islamic groups such as, MILF, Abu Sayyaf, and Maute group. The emergence of these groups was caused by the schism in the older militant groups such as MNLF and MILF. However, the disunity of the older militant groups and the emergence of the so called "splinter groups" finally created conflicts among them. On the other hand, those groups bear resemblance in their family origins. This article highlighted the family networking inside the radical Islamic groups especially the Maute group. This group can grow rapidly because of the family bond between their founders and members with the Moro Islamic Liberation Front (MILF). The family bond became their protector and also vital point for the rise of radicalism in the Maute group.
\end{abstract}

Keywords: southern Philippines; radical islamic groups; MMILF; maute group; family bond.

\section{Pendahuluan}

Konflik berkepanjangan di daerah Filipina Selatan antara pemerintah Filipina dan kelompok-kelompok radikal Islam kembali memanas seturut naiknya presiden Rodrigo Duterte pada 2016 lalu. Mantan wali kota Davao City—salah satu kota terbesar di wilayah Filipina Selatan - ini masih harus bergelut dengan rongrongan kelompokkelompok Islam radikal seperti MILF (Moro Islamic Liberation Front), BIFF (Bangsamoro Islamic Freedom Fighter), serta yang paling brutal, Abu Sayyaf. Ancaman yang ditimbulkan oleh kelompok-kelompok tersebut bahkan sudah mencakup skala regional, mengingat beberapa bagian dari mereka kerapkali terlibat dalam pembajakan kapal serta penyanderaan warga negara asing yang melintas di perairan sekitar Mindanao, Filipina Selatan. Ancaman terhadap keamanan Filipina makin bertambah setelah muncul kelompok radikal Islam baru yang menyebut dirinya sebagai Khilafah Islamiyah Movement (KIM), atau yang lebih populer dengan sebutan Kelompok Maute. Kelompok ini mulai menyita perhatian saat mereka menembaki konvoi kendaraan Presiden Duterte yang tengah meninjau lokasi pertempuran di kota Butig, provinsi Lanao del Sur, Davao, Filipina Selatan, pada Sabtu, 25 November 2016. Presiden Duterte saat itu bermaksud untuk memantau secara langsung aksi pasukan Filipina yang tengah berusaha membebaskan kota Butig dari penguasaan Kelompok Maute. Sebelumnya, pada Jumat, 24 November 2016, 
sejumlah 50 sampai 100 pasukan Maute menyerbu dan menduduki balaikota Butig. Mereka bahkan mengibarkan bendera hitam milik ISIS di depan lokasi balaikota tersebut. ${ }^{1}$

Peningkatan agresifitas Kelompok Maute mulai terjadi sejak awal 2016 yang terlihat dari empat serangan besar yang mereka lakukan, termasuk saat mereka merebut kota Butig pada November 2016. Di sisi lain, kelompok ini justru makin agresif setelah militer Filipina sukses menghancurkan markas besar mereka dalam operasi militer pada Februari 2016 lalu. Dalam operasi berdurasi 10 hari tersebut, tentara Filipina mengklaim telah sukses menewaskan Omar Maute - salah satu pendiri sekaligus tokoh utama kelompok inibeserta 50 orang pengikutnya. ${ }^{2}$ Namun, Omar Maute ternyata belum tewas. Ia kembali muncul untuk memimpin serangan terhadap kota Butig pada November 2016 lalu, sekaligus menemui juru runding dari pemerintah Filipina demi membicarakan gencatan senjata pascapertempuran tersebut. ${ }^{3}$

Kelompok Maute merupakan salah satu kelompok Islam radikal yang menyempal dari organisasi perlawanan tradisional di Filipina Selatan, khususnya MILF. Dalam perkembangannya, kelompok ini kemudian menyatakan dukungannya kepada ISIS sekaligus mengadopsi metode-metode mereka. Kelompok Maute melakukan penculikan, pemenggalan, bahkan pengeboman untuk mengacaukan situasi di Filipina Selatan. Kelompok Maute juga turut mengadopsi simbol-simbol ISIS seperti salam tauhid

Dikutip dari

http://cnnphilippines.com/news/2016/11/28/military -offensive-maute-group.html, diakses tanggal 25 Januari 2017 pukul 16.06.

2 Dikutip dari http://news.abscbn.com/nation/regions/v1/02/28/16/rebel-leader-2brothers-killed-in-lanao-clashes, diakses tanggal 25 Januari 2017 pukul 16.49.

3 Dikutip dari http://news.abscbn.com/news/12/05/16/attempts-to-talk-peacewith-the-maute-group-underway, diakses tanggal 27 Januari 2017 pukul 13.30. (mengacungkan jari telunjuk ke atas), memakai bendera hitam khas ISIS, serta mengenakan pakaian serba oranye kepada dua orang pekerja tambang yang mereka penggal pada April 2016. Kelompok Maute juga terkenal karena cenderung menolak bernegosiasi dengan pemerintah Filipina.

Pengaruh ISIS terhadap aksi-aksi kelompok jihadis yang lain dalam beberapa tahun terakhir ini memang menunjukkan peningkatan signifikan. Saat ISIS mulai terdesak di wilayah-wilayah inti seperti Irak dan Suriah, mereka mengalihkan fokusnya ke wilayah-wilayah lain seperti Eropa, Afrika, dan Asia Tenggara dengan memanfaatkan jaringan diaspora Islam. Terkait fenomena ini, Najamuddin Khairur Rijal menyatakan bahwa ${ }^{4}$ :

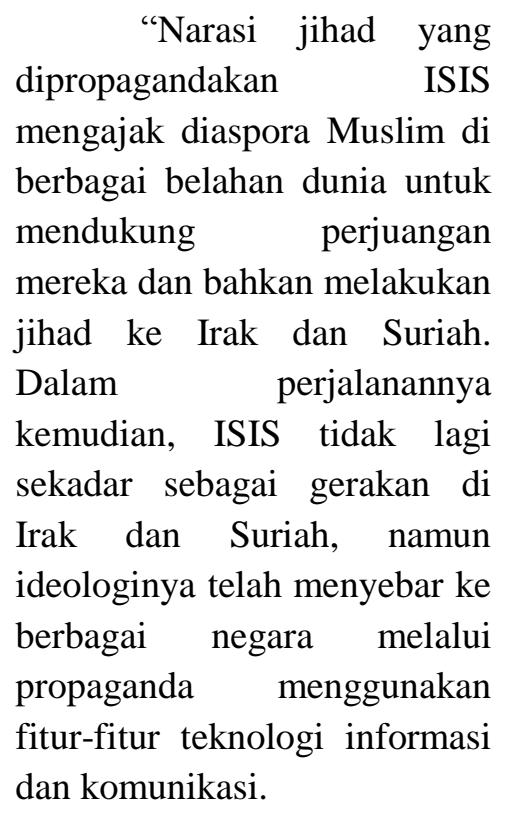

Kelompok Maute dan kelompokkelompok lain seperti Abu Sayyaf serta Anshaur al Khalifah merupakan generasi terbaru dari kelompok radikal Islam di Filipina Selatan. Mereka umumnya didirikan oleh tokoh-tokoh muda dari organisasi yang lebih senior seperti MILF dan MNLF. Kelompok-

\footnotetext{
${ }^{4}$ dikutip dari "Eksistensi dan Perkembangan ISIS: dari Irak hingga Indonesia", Jurnal Ilmiah Hubungan Internasional. Vol.13, No.1 (September 2017) $: 48$
} 
kelompok baru ini cenderung menggunakan metode kekerasan yang lebih brutal dan cenderung lebih mengarah ke tindakan kriminal. dibandingkan kelompok-kelompok militan yang lebih senior.

Afiliasi terhadap ISIS hanyalah salah satu faktor yang menunjang aksi-aksi kejahatan yang dilakukan oleh Kelompok Maute. Faktor lain yang tidak kalah penting adalah penggunaan ikatan keluarga dalam merekrut anggota atau membina jaringan dengan kelompok-kelompok radikal lainnya. Ikatan keluarga ini memegang peranan yang sangat vital, khususnya dalam metode gerilya yang mereka terapkan saat berperang. Melalui ikatan keluarga, Kelompok Maute dapat memperoleh perlindungan dari kelompokkelompok militan lainnya sekaligus mendapatkan bantuan logistik selama bergerilya.

Tulisan ini selanjutnya bertujuan untuk memetakan jaringan kekeluargaan yang menghubungkan Kelompok Maute dengan kelompok-kelompok Islam radikal atau separatis lainnya di wilayah Filipina Selatan. Pertanyaan penelitian yang ingin dijawab adalah: bagaimana hubungan keluarga yang terjalin antara Kelompok Maute dengan kelompok-kelompok separatis lainnya dapat berkontribusi terhadap perkembangan kelompok ini?

\section{Sejarah Kelompok Maute}

Dawla al Islamiyah-atau yang lebih dikenal dengan sebutan "Kelompok Maute"-diperkirakan telah berdiri sejak 2012 atas prakarsa kakak-beradik Abdullah dan Omarkhayam Maute. Keduanya dikenal sebagai tokoh lokal yang cukup berpengaruh di kawasan Lanao del Sur serta memiliki hubungan kekerabatan dengan petinggi MILF. Abdullah dan Omar, beserta satu lagi saudara mereka-Mohammad Khayam Maute-- berasal dari suku Maranaw (secara etimologis berarti "orang dari danau Lanaw"), salah satu kelompok suku yang ada di Filipina Selatan.

Kakak-beradik Abdullah dan Omar Maute sebelumnya sempat merantau ke Uni Emirat Arab sebagai pekerja kontrak sekaligus mendalami ilmu agama di negara tersebut. ${ }^{5}$ Selepas pulang dari Uni Emirat Arab, mereka memutuskan untuk bergabung ke MILF sebelum membentuk kelompoknya sendiri pada 2012. Pada masa awal berdirinya, Kelompok Maute lebih dikenal sebagai kelompok kriminal kecil di Lanao del Sur. Mereka adalah kelompok yang kerap memeras perusahaan-perusahaan bus di wilayah Lanao del Sur untuk mendapatkan logistik. ${ }^{6}$

Perubahan Kelompok Maute dari sindikat kriminal menjadi kelompok militan dimulai saat mereka menyerang sebuah pos pemeriksaan militer di kota Madalum, daerah Lanao del Sur pada 2013. Pihak militer Filipina mengklaim bahwa kelompok penyerang tersebut berasal dari kelompok pimpinan Abdullah dan Omar Maute yang memperoleh senjata dari para jihadis-jihadis asing yang bertempur di Mindanao pada 2012. ${ }^{7}$ Aksi-aksi kelompok ini mencapai puncaknya pada 2016 lewat berbagai serangan seperti ${ }^{8}$ :

1. Penculikan dan pemenggalan dua pekerja tambang di wilayah Lanao del Sur pada April 2016.

2. Penyerangan penjara Butig untuk membebaskan anggotanya yang ditahan pada 28 Agustus 2016

\footnotetext{
5 https://www.trackingterrorism.org/group/mautegroup-islamic-state-lanao-daulat-ul-islamiyadaulah-islamiyah, diakses tanggal 30 Januari 2017 pukul 14.30.

${ }^{6}$ http://www.newmandala.org/mindanao-after-thephilippines-presidential-elections/, diakses tanggal 30 Januari 2017 pukul 14.39.

${ }^{7}$ http://cnnphilippines.com/regional/2016/03/02/But ig-Lanao-del-Sur-clashes-Maute-group.html, diakses tanggal 30 Januari 2017 pukul 14.00.

${ }^{8}$ https://tirto.id/kelompok-maute-waralaba-baru-isisdi-filipina-b593, diakses tanggal 25 Januari 2017 pukul 16.22.
} 
(berhasil meloloskan puluhan tahanan).

3. Pemboman sebuah pasar di Davao City pada 2 September 2016 (menewaskan 14 orang dan melukai 70 orang).

4. Upaya pengeboman terhadap Kedutaan Besar Amerika Serikat di Filipina pada 25 November 2016.

Pihak militer Filipina menyatakan bahwa Abdullah dan Omar Maute merupakan bagian dari jaringan teroris Jamaah Islamiyahkelompok radikal di kawasan Asia Tenggara yang terlibat dalam peristiwa Bom Bali I pada 2002 serta memiliki jaringan dengan AlQaeda. ${ }^{9}$ Belakangan, ketika aktivitas Jamaah Islamiyah menunjukkan kecenderungan penurunan, Kelompok Maute mengalihkan dukungannya kepada ISIS terhitung sejak April 2015.

Perpindahan afiliasi Kelompok Maute ke ISIS terjadi akibat hancurnya jaringan-jaringan Jamaah Islamiyah di Asia Tenggara. Alasan utama perpindahan afiliasi ini belum diketahui secara pasti, tetapi kemungkinan besar diakibatkan oleh popularitas ISIS yang sangat tinggi di Asia Tenggara serta kemampuan finansial ISIS yang besar untuk mendanai operasi-operasi militer Kelompok Maute. Sebagai entitas baru dan masih dalam taraf perkembangan, Kelompok Maute tentu saja membutuhkan hal-hal tersebut. ISIS adalah pintu masuk bagi kelompok baru seperti Maute untuk masuk ke dalam jaringan Islam radikal transnasional.

Zachary Abuza, profesor dari National War College Washington DC, mencatat bahwa sudah ada enam kelompok di Asia Tenggara yang menyatakan diri berbaiat kepada ISIS, termasuk Anshaur al Khalifah Filipina dan Dawlah Islamiyah (sebutan lain Kelompok

\footnotetext{
${ }^{9}$ http://www.gmanetwork.com/news/story/557070/n ews/nation/milf-group-in-lanao-not-terroristsdisgruntled-by-peace-deal-s-fate, diakses tanggal 25 Januari 2017 pukul 16.59.
}

Maute) di Filipina. Kedua kelompok ini memiliki hubungan erat dengan sel-sel teroris di Malaysia dan Indonesia. Selanjutnya, Abuza menyatakan bahwa:

"IS is trying to bring the
different groups together
under a single chain of
command, calling each of the
groups a "battalion." With
the territory and manpower
of parts of the MILF, IS and
its Philippine affiliates may
finally declare the
establishment of a province
or wilayat. ${ }^{10, "}$

Kelompok Maute merupakan salah satu kelompok di Filipina yang menyatakan diri sebagai perwakilan wilayat ISIS di Filipina. Langkah Kelompok Maute sebenarnya mengikuti proses serupa yang sebelumnya sudah dilakukan oleh Kelompok Santoso di Indonesia. Kelompok Santoso merupakan sempalan/splinter group dari kelompok Jamaah Ansharut Tauhid (perwakilan Al Qaeda di Indonesia) yang berperang di pedalaman Sulawesi. Kelompok yang memiliki nama lain "Mujahidin Indonesia Timur" (MIT) ini terbentuk pada 2012 dan telah menyatakan kesetiaan kepada ISIS (baiat) sejak 2014 atau hanya sekitar satu tahun setelah terbentuknya ISIS pada 2013 lalu.

Sementara itu, James Franco dari Centre of Excellence for National Security (CENS) S. Rajaratnam School of International Studies Nanyang Technological University, membantah bahwa Kelompok Maute telah masuk ke dalam jaringan ISIS di Asia Tenggara. Ia membenarkan bahwa Kelompok Maute sudah menyatakan kesetiaannya kepada ISIS lewat mekanisme "bayah", tetapi pihak

\footnotetext{
${ }^{10}$ Dikutip dari http://www.newmandala.org/duterteprospects-bangsamoro-peace/, diakses tanggal 30 Januari 2017 pukul 10.49.
} 
ISIS sendiri belum menerima pernyataan tersebut. Franco memaparkan bahwa:

"But beyond MG's pledge of
allegiance, or bayah, to IS,
operational and financial
links with the latter were
more imaginary than real. IS
has yet to recognise the MG's
bayah, the latter a critical
part of jihadist practice. But
while Filipino militants'
ideological links with
transnational jihadist
narratives remain superficial,
the local political milieu in
Mindanao continues to fuel
dissent."

Afiliasi antara ISIS dan Kelompok Maute terlihat jelas saat kelompok ini menyerbu dan menduduki kota Marawi. Dalam peperangan yang masih berkecamuk sejak 23 Mei 2017 lalu, Kelompok Maute bekerjasama dengan Isnilon Hapilon, tokoh pimpinan kelompok Abu Sayyaf yang dipercaya sebagai pimpinan utama ISIS di Filipina. Di sisi lain, Maute Bersaudara (Omar dan Abdullah) sangat gencar mempromosikan hubungan mereka dengan ISIS. Dalam laman Facebook dan Youtube-nya, kedua bersaudara ini memperlihatkan foto-foto dan video mereka tengah memakai atribut ISIS sebagai sarana propaganda sekaligus merekrut anggotaanggota baru untuk bertempur di Marawi. ${ }^{12}$

\section{Ikatan Keluarga dengan Jaringan Separatis}

Kelompok Maute bukanlah sebuah kelompok yang benar-benar baru, tetapi

\footnotetext{
$11 \quad$ Dikutip dari http://www.newmandala.org/mindanao-after-thephilippines-presidential-elections/, diakses tanggal 30 Januari 2017 pukul 10.59.

12 Dikutip dari http://www.reuters.com/article/usphilippines-militants-maute-idUSKBN19302Q, diakses tanggal 30 Januari 2017 pukul 11.00
}

mereka berdiri dengan memanfaatkan jaringanjaringan yang sudah ada. Sebagian besar anggota Kelompok Maute berasal dari mantan anggota MILF, MNLF, atau Abu Sayyaf yang meninggalkan organisasinya. Namun, perpindahan orang-orang ini ke Kelompok Maute tidak lantas menghilangkan jaringan lama mereka. Hal ini terjadi karena sebagian besar petinggi dan anggota kelompokkelompok separatis di Filipina Selatan, baik yang beraliran sekuler seperti MNLF maupun yang berideologi agama seperti MILF, ternyata masih memiliki hubungan keluarga.

Kelompok Maute sebagai entitas baru pun turut memanfaatkan ikatan keluarga tersebut. Dalam laporan investigasi oleh Chiara Zambrano dari $A B S-C B N$ News, terungkap bahwa Maute bersaudara merupakan sepupu dari Azisa Romato-istri dari mendiang wakil ketua bidang militer MILF, Alim Abdul Aziz Mimbantas. ${ }^{13}$ Hal ini dikemukakan langsung oleh Jannati Mimbantas-adik Aziz Mimbantas sekaligus komandan satuan militer MILF, North Eastern Mindanao Front, yang berkedudukan di Butig.

Liputan tersebut juga mengungkapkan bahwa Maute bersaudara memiliki hubungan kekerabatan dengan Sanusi-seorang ahli bom asal Indonesia yang disebut-sebut sebagai kepala Jamaah Islamiyah di Mindanao. Sanusi merupakan mentor sekaligus sahabat dari Abdullah dan Omar. Di sisi lain, Sanusi sendiri diketahui menikahi seorang putri dari Aziz Mimbantas. Hal ini membuat Sanusi tidak hanya memiliki hubungan pribadi, namun juga ikatan kekerabatan dengan kakak-beradik Maute, meskipun fakta ini dibantah oleh Jannati Mimbantas.

Kedekatan antara keluarga Maute dengan kelompok-kelompok radikal khususnya MILF terjadi karena beberapa faktor. Pertama,

\footnotetext{
13 http://k2.abs-cbnnews.com/focus/03/03/16/theties-that-bind-milf-and-maute-group, diakses tanggal 30 Januari 2017 pukul 16.05.
} 
wilayah provinsi Lanao del Sur-tempat Kelompok Maute memulai aksinya—sejak lama dikenal sebagai basis dari kelompok MILF. Mereka bahkan memakamkan dua tokoh utama MILF, Salamat Hashim (ketua) dan Aziz Mimbantas (wakil ketua) sekaligus membangun sembilan base commands dan unit-unit militer lainnya di provinsi ini. Kedua, keluarga Maute merupakan keluarga terpandang serta memiliki pengaruh politik dan ekonomi sangat besar, tidak hanya di wilayah Lanao del Sur, tetapi bahkan mencakup seluruh wilayah Mindanao. Farhana Mauteibu dari kakak beradik pimpinan Kelompok Maute-dijuluki sebagai "matriarch" yang memiliki bisnis konstruksi dan properti dengan kekayaan yang sangat besar di wilayah Lanao del Sur. ${ }^{14}$ Farhana juga dikenal sebagai seorang broker politik mengingat ia memiliki hubungan yang sangat dekat dengan para politisi terkemuka di Mindanao, khususnya para pemimpin MILF.

Keluarga Maute di bawah pimpinan Farhana diklaim memiliki pasukan pribadi yang melibatkan ketujuh anak mereka, termasuk kakak-beradik Abdullah dan Omar Maute yang kelak menjadi pendiri Kelompok Maute. Pembentukan prajurit pribadi tersebut disebabkan oleh kondisi Mindanao yang sangat rawan terhadap kekerasan politik yang terjadi antara keluarga-keluarga berpengaruh di wilayah tersebut. Joseph Franco bahkan mengkalim bahwa kekerasan di Marawi sebenarnya dimulai setelah keluarga Maute terlibat dalam sengketa kontrak pembangunan dengan Walikota Butig Dimnatang Pansar. ${ }^{15}$

14 http://news.abs-cbn.com/focus/06/23/17/themautes-of-the-philippines-from-monied-family-toislamic-state, diakses tanggal 13 September 2017 pukul 16.45 .

15 "She [Farhana Maute] is only a businesswoman. But, her clan was involved in a bitter political dispute with the mayor of Butig. And that probably got her into trouble", http://news.abscbn.com/focus/06/23/17/the-mautes-of-thephilippines-from-monied-family-to-islamic-state, diakses tanggal 13 September 2017 pukul 17.00.
Belakangan, pemerintah Filipina akhirnya menangkap Farhana Maute bersama suaminya, Cayamore, karena diduga terlibat dalam membiayai

Keberadaan MILF secara turun temurun di Butig menyebabkan interaksi mereka dengan keluarga Maute menjadi sangat intens. Hal inilah yang kemudian memicu hubungan pertemanan, kekerabatan, bahkan hubungan darah hasil dari bahkan pernikahan di antara kelompok Maute dan MILF. Ikatan ini pun tidak hanya terjalin di tataran elite pimpinan organisasi saja, tetapi juga di kalangan anggota di akar rumput.

Kedekatan antara MILF dan Kelompok Maute terlihat saat militer Filipina melakukan serangan berskala besar di markas Maute di Butig. Militer Filipina berhasil menemukan beberapa atribut MILF dan sebuah mayat yang mengenakan seragam MILF di lokasi pertempuran. Namun, MILF membantah keterlibatan mereka di pertempuran tersebut lewat pernyataan Jannati Mimbantas selaku petinggi di kawasan Butig. Ia mengaku bahwa pasukannya sampai harus memindahkan markas mereka yang terletak tidak jauh dari markas Kelompok Maute yang menjadi sasaran penyerbuan militer Filipina. Meskipun MILF tidak terlibat secara organisasi dengan Kelompok Maute, tetapi Jannati Mimbantas memaparkan bahwa pihaknya tidak mampu menghalangi anggota MILF yang secara sukarela terlibat ke dalam pertempuran untuk menyelamatkan anggota keluarganya yang bergabung dengan Kelompok Maute. ${ }^{16}$

\section{Ikatan Keluarga di Filipina Selatan}

Ikatan keluarga (family bonds) telah menjadi salah satu faktor penting dalam eksistensi Kelompok Maute di Filipina Selatan. Ikatan keluarga dapat menembus sekat-sekat organisasi dan perbedaan ideologi antara 16 Ibid, diakses tanggal 31 Januari 2017 pukul
16.54. 
Kelompok Maute dan MILF serta menimbulkan solidaritas di antara anggotaanggota mereka, khususnya dalam menghadapi situasi darurat seperti serangan militer. Hal ini tidak hanya terbentuk di antara Kelompok Maute dan MILF saja, namun juga di antara kelompok-kelompok militan di Filipina Selatan lainnya.

Samsu Rizal Panggabean, salah satu akademisi yang terlibat dalam pembebasan sandera Abu Sayyaf di Mindanao pada awal 2016 lalu, mengungkapkan hal tersebut. Rizal mengungkapkan berdasarkan pengalamannya berinteraksi dengan kelompok Abu Sayyaf bahwa ikatan kekeluargaan, patronase, dan senioritas sangat berperan dalam jaringan kelompok-kelompok Islam radikal di Filipina Selatan. Banyak keluarga di wilayah tersebut yang sudah menjadi bagian dari kelompokkelompok Islam radikal secara turun-temurun hingga tiga generasi.

“... cara Abu Sayyaf ini di organisasi itu basisnya keluarga. Jadi kalau ada satu kelompok yang terdiri dari 33 orang misalnya ya, itu kakeknya di situ, om di situ, atau paman-paman di situ, terus ayahnya di situ, sampai cucunya di situ, termasuk cucunya yang masih berumur 10 tahun pun sudah pegang senjata." 17

Rizal menambahkan bahwa sebenarnya kelompok-kelompok ini sendiri mengalami jarak antar generasi (generation gap) antara generasi muda dan tua. Generasi muda di kelompok-kelompok ini cenderung lebih brutal dibandingkan generasi tua yang mulai moderat.

\footnotetext{
${ }^{17}$ Dikutip dari wawancara penulis dengan Samsu Rizal Panggabean dalam https://tirto.id/terlalu-naifkalau-tanpa-uang-tebusan-bliy, diakses tanggal 7 Februari 2017 pukul 08.15
}

Namun, hal ini tidak menghalangi mereka untuk tetap saling melindungi. Rizal menyatakan bahwa:

$$
\text { "Jadi di organisasi }
$$

[Abu Sayyaf] sebagai unit-unit yang terpisah yang hanya diikat oleh kekeluargaan. Jadi mereka saling melindungi. Mati-matian saling melindungi karena kamu melindungi pamanmu atau melindungi keponakanmu kan...Jadi ya melindungi bukan karena dia anggota Abu Sayyaf tapi ponakan saya, atau cucu saya. ${ }^{18}$

Kecenderungan yang terjadi di Abu Sayyaf juga muncul di Kelompok Maute dan kelompok-kelompok Islam radikal lainnya di Filipina Selatan. Mereka sama-sama mengandalkan ikatan keluarga (family bonds) sebagai modal utama dalam membangun gerakannya. Ikatan keluarga menciptakan kewajiban tersendiri bagi setiap anggota kelompok Islam radikal di Filipina Selatan untuk melindungi sesama rekannya, bahkan jika rekan tersebut berasal dari organisasi dengan latar belakang ideologi yang berbeda.

Dalam sebuah organisasi yang dicap terlarang, berseberangan dengan negara sehingga menjadi target penghancuran, serta rawan disusupi mata-mata, ikatan keluarga selanjutnya menjadi basis untuk membangun kepercayaan (trust) di antara anggota-anggota kelompok Islam radikal. ${ }^{19}$ Posisi dari ikatan keluarga (family bonds) ini bahkan cenderung lebih penting daripada afiliasi kepada kelompok-kelompok radikal transnasional

\footnotetext{
${ }^{18}$ Ibid, op.cit.

19 "Jadi cara mengorganisasinya [Abu Sayyaf] basis keluarga. Nah, makanya kita juga mementingkan arti penting keluarga. Jadi orang-orang Sulu yang di tim kita itu juga cucunya si "ini" yang keponakannya si "ini"'. Dekat. Jadi trust itu basisnya keluarga." (Ibid, op.cit).
} 
seperti Al-Qaeda, Jamaah Islamiyah atau ISIS. Dalam kasus Kelompok Maute, misalnya, kelompok ini bisa saja mengalihkan afiliasinya dari Jamaah Islamiyah/Al-Qaeda ke ISIS tanpa menemui penolakan atau kendala berarti. Hal seperti ini tentu saja tidak mungkin terjadi dalam konteks ikatan keluarga yang tidak bisa diputuskan secara sepihak.

Munculnya ikatan keluarga sebagai basis dari jaringan kelompok radikal muncul dari sejarah konflik di kawasan Filipina Selatan yang panjang sekaligus belum terselesaikan hingga saat ini. Kondisi konflik yang berlarut-larut sangat mempengaruhi kehidupan sehari-hari di wilayah Filipina Selatan, khususnya akibat absennya otoritas negara di wilayah ini secara de facto. Absennya negara, khususnya dalam menciptakan rasa aman (security), membuat masyarakat di Filipina Selatan mencari institusi-institusi lain yang bisa menyediakannya. Masyarakat akhirnya mengorganisasi diri serta membentuk kelompok-kelompok keamanan non-negara yang dipimpin oleh orang-orang berpengaruh setempat (local elites). Jaringan yang dimanfaatkan untuk membentuk kelompokkelompok semacam ini biasanya bersumber dari ikatan keluarga atau pertemanan karena jalannya konflik yang berlarut-larut membuat warga di Filipina Selatan cenderung tidak mudah mempercayai orang luar.

Ikatan keluarga bukanlah satu-satunya modal bagi terbentuknya kelompok-kelompok keamanan ini. Ikatan keluarga ini biasanya berhubungan erat dengan dua faktor lainnya: kesukuan dan kesetiaan terhadap tokoh yang berpengaruh. Perpaduan dari ketiganya menciptakan sebuah struktur sosial yang sangat patriarkis dengan sentimen kesukuan yang sangat akut. $^{20}$ Ikatan keluarga dan kesukuan ini tidak hanya mampu menyediakan rasa aman saja, tetapi juga menyediakan hal-

\footnotetext{
${ }^{20}$ Dikutip dari The Contested Corners of Asia: The Case of Mindanao, Fermin Adriano \& Thomas Parks, The Asia Foundation (2013) pp.21
}

hal lain untuk menjamin kehidupan anggotanya seperti pekerjaan, jaring pengaman sosial (social safety net), dan bantuan-bantuan lain yang berguna bagi penghidupan mereka sehari-hari. ${ }^{21}$ Faktor-faktor ini menyebabkan masyarakat di Filipina Selatan lebih menunjukkan loyalitasnya di hadapan ikatan keluarga, elite lokal, dan suku jika dibandingkan dengan posisi mereka sebagai warga negara Filipina. Mereka lebih mampu mengidentifikasikan dirinya sebagai bagian dari suku atau klan tertentu karena ikatanikatan tersebut dapat memunculkan rasa memiliki (sense of belonging) dibandingkan ikatan sebagai warga negara Filipina.

Salah satu faktor yang turut mendukung ikatan keluarga di Filipina Selatan adalah fenomena patron-klien yang sangat kental. Riset dari The Asia Foundation menunjukkan bahwa $70 \%$ penduduk di wilayah ini mengandalkan elite-elite lokal untuk melindungi mereka serta mencari keadilan. ${ }^{22}$ Ketergantungan yang sangat besar terhadap patronase membuat para elite lokal di Filipina Selatan dapat memobilisasi massa dengan mudah. Thomas Kiefer, seorang peneliti isu-isu Filipina Selatan, menggarisbawahi bahwa ikatan keluarga semacam itu bisa masuk ke dalam berbagai aspek kehidupan seperti politik, ekonomi, dan mobilisasi militer sehingga membuat peranan dinasti politik (political families) sangatlah dominan dalam perpolitikan lokal di Filipina Selatan. ${ }^{23}$

Filipina Selatan merupakan daerah yang secara de facto dikuasai oleh para dinasti politik tertentu. Dinasti-dinasti ini kerap terlibat konflik politik demi memperebutkan

\footnotetext{
${ }^{21}$ Ibid, op.cit.

${ }^{22}$ Ibid, op.cit.

23 “...that kinship relationship could penetrate into various aspects of life, including political, economic and military mobilization. Therefore, in the post-war Philippines, political families controlled and dominated local politics in the southern areas". Kiefer, Thomas. 1970. Modes of Social Action in Armed Combat: Affect, Tradition and Reason in Tausug. New Series, Vol. 5, No. 4.
} 
kekuasaan yang berujung pada kekerasan seperti yang terjadi saat keluarga Ampatuan menyerang rombongan kampanye keluarga Mangudadatu menjelang pemilihan gubernur Mindanao pada 2009 lalu dalam peristiwa yang dikenal sebagai "Maguindanao Massacre". Peristiwa kekerasan tersebut menunjukkan bahwa para ikatan-ikatan keluarga di Filipina Selatan memiliki kapasitas untuk melaksanakan kekerasan, khususnya dalam kepemilikan senjata dan amunisi. Di sisi lain, kapasitas para dinasti politik untuk memberikan perlindungan dari segi keamanan adalah faktor yang sangat penting bagi Kelompok Maute. Melalui afiliasinya dengan dinasti-dinasti berpengaruh di dalam MILF, Kelompok Maute dapat terhindar dari konflik dengan sesama kelompok Islam radikal di Filipina Selatan, setidaknya untuk jangka waktu pendek, mengingat ikatan keluarga dalam perpolitikan di Filipina sebenarnya sangat rapuh. Keluarga-keluarga dan sukusuku di Filipina Selatan sangat rentan mengalami perpecahan saat timbul persaingan memperebutkan sumber daya tertentu di antara mereka.

\section{Perlawanan}

Jaringan Keluarga sebagai Modal

Rommel C. Banlaoi, peneliti dari Philippine Institute for Peace, Violence and Terrorism Research dan Direktur Center for Intelligence and National Security Studies menyatakan bahwa ikatan keluarga menyediakan akses yang mudah dan luas dalam perekrutan anggota-anggota baru bagi kelompok-kelompok radikal di seluruh dunia. Banlaoi merujuk kepada fenomena-fenomena serangan teroris dunia yang dilakukan oleh keluarga seperti penembakan klub gay di Orlando pada Mei 2016 lalu oleh Omar Mateen - anak dari seorang mantan jihadis di Afghanistan serta penembakan Boston Marathon pada April 2013 yang melibatkan kakak-beradik Dzokhar dan Tamerlan Tsarnaev. Fenomena ini muncul karena ISIS menyasar kegeraman dan kegelisahan komunal yang muncul dalam komunitas keluarga tersebut.

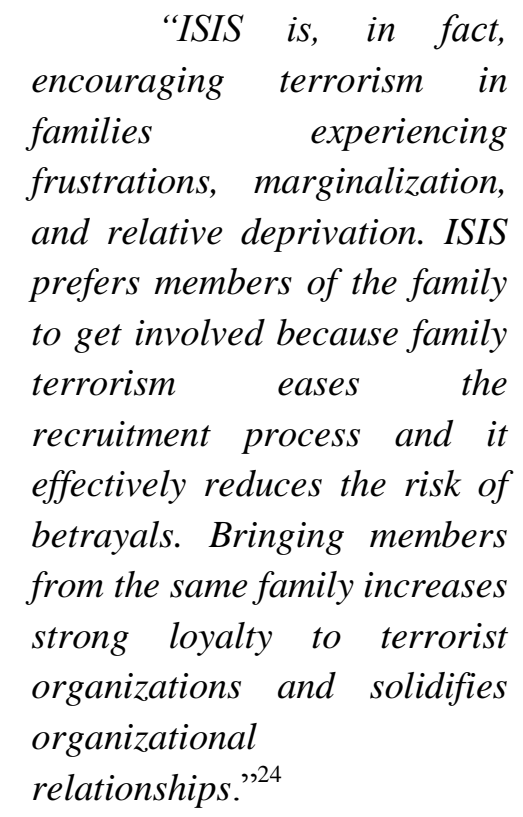

Jaringan keluarga juga menjadi kunci bagi Kelompok Maute dalam menghadapi pemerintah Filipina khususnya pihak militer. Konflik bersenjata antara militer Filipina dan Kelompok Maute selama ini tergolong ke dalam asymmetrical conflict dimana terdapat kesenjangan kekuatan yang sangat besar antara dua pihak yang berkonflik ${ }^{25}$, khususnya antara pihak negara (state) melawan aktor non-negara (non-state). Ikatan keluarga, selanjutnya, menyediakan sumber daya yang sangat besar bagi Kelompok Maute dalam menghadapi kebijakan-kebijakan represif yang dilancarkan oleh pemerintah Filipina.

Ekaterina Stepanova (2008) menyatakan bahwa dalam sebuah konflik

\footnotetext{
${ }^{24}$ https://www.rappler.com/thoughtleaders/173037-maute-group-rise-family-terrorism, diakses tanggal 13 September 2017 pukul 18.20. 25 "Asymmetry in armed conflict has been most often interpreted as awide disparity between the parties, primarily in military and economic power, potential and resources. As well as being overly militarized, this approach is both too broad and too narrow to adequately describethe nature of terrorism in asymmetrical conflicts", dikutip dari Stepanova, Ekaterina. "Terrorism in Asymmetrical Conflict: Ideological and Structural Aspects". New York: Oxford University Press (2008) pp 14 - 15.
} 
yang bersifat asimetris, terdapat sebuah kondisi yang disebut sebagai two-way asymmetry. Kondisi ini mencakup positive asymmetry yaitu penggunaan kekuatan superior oleh aktor konvensional yang lebih kuat (negara) dan negative asymmetry yaitu penggunaan sumber daya dari aktor yang lebih lemah dengan memanfaatkan kelemahan (vulnerabilities) yang dimiliki oleh aktor konvensional. $^{26}$

Kelompok Maute sebagai pengguna metode negative asymmetry akan selalu berusaha menggiring pemerintah Filipina ke ranah peperangan yang mereka kuasai. Ranah peperangan tersebut biasanya terbagi dalam dua konteks: material dan immaterial. Dalam ranah material, Kelompok Maute menggunakan metode gerilya dan perang kota untuk mengatasi kurangnya perlengkapan militer dan jumlah pasukan mereka jika dibandingkan dengan militer Filipina. Sementara itu, dalam ranah immaterial, faktor ideologi memegang peranan yang sangat penting. Keberhasilan Kelompok Maute dalam peperangannya melawan militer Filipina terletak dari kepiawaiannya dalam memainkan isu ideologi dan identitas, khususnya perjuangan umat Islam melawan pihak Filipina yang dikonstruksikan sebagai penindas beragama Katolik. Dalam konteks konflik di Mindanao, Kelompok Maute menggunakan ikatan keluarga ini sebagai modal dalam melancarkan perang ideologi terhadap pemerintah Filipina. Ikatan keluarga yang dipadukan dengan jaringan antar aktor terorisme transnasional serta penggunaan propaganda melalui internet adalah ujung tombak bagi perang ideologi yang dilancarkan Kelompok Maute.

Carlos Marighella dalam Minimanual of the Urban Guerrilla menyatakan bahwa para pelaku gerilya boleh saja kalah dari segi peralatan militer, namun mereka harus bisa menang dalam hal moral atau alasan mereka

${ }^{26}$ Ibid, pp 20. berjuang. ${ }^{27}$ Dalam konteks Kelompok Maute, mereka berhasil mengonsepkan sebuah ide perlawanan berbasis identitas Islam yang menjadi kunci untuk merekrut anggotaanggota baru sekaligus menaikkan moralitas perjuangan mereka. Kelompok Maute mampu menciptakan polarisasi ideologi dan identitas yang ekstrim antara mereka dan pemerintah Filipina sebagai kunci untuk menyeimbangkan kekuatan mereka yang timpang dari sisi militer. ${ }^{28}$ Jaringan keluarga, selanjutnya, mampu menambah dimensi baru dalam peperangan ideologi ini dari sebatas peperangan antara "Islam vs Katolik" menjadi antara "keluarga vs musuh keluarga". Polarisasi ini dapat semakin meningkatkan permusuhan dengan pemerintah Filipina sekaligus membuat persatuan di internal Kelompok Maute semakin solid di tengah semakin gencarnya represi oleh pemerintah dan militer Filipina.

\section{Kesimpulan}

Kelompok Maute merupakan salah satu kelompok jihadis di Asia Tenggara yang menggunakan jaringan keluarga untuk mempertahankan eksistensinya. Ikatan keluarga secara teknis dapat membantu para jihadis tersebut untuk dalam menjalankan aksiaksinya. Kelompok Maute mendapatkan banyak sekali keuntungan dari ikatan keluarga mereka. Pertama, mereka mendapatkan jaringan yang kuat untuk berlindung dari kejaran tentara pemerintah Filipina. Kedua, mereka memperoleh asupan logistik dengan

27 “...the conventionally weaker side's 'arms are inferior to the enemy's', but 'from a moral point of view' the former enjoys 'anundeniable superiority', dikutip dari Ibid, pp. 21.

28 "Sharp ideological disparity is the main condition for turning what may seem a one-way asymmetry

into a two-way one. It is also the basis for a host of other qualitativeimbalances and dissimilarities, such as the disparities in purpose and in understanding and interpretation of 'security', 'victory',

'defeat' and so on, dikutip dari Ibid, pp. 22. 
jumlah yang sangat besar selama menjalankan aktivitasnya. Ketiga, perekrutan melalui keluarga memastikan bahwa anggota yang bergabung memiliki loyalitas yang sangat tinggi selain militansi yang baik.

Ikatan keluarga yang diaktifkan oleh Kelompok Maute bahkan mampu melintasi sekat-sekat organisasi. Hal ini ditunjukkan saat beberapa anggota kelompok separatis MILF turut membantu keluarganya yang menjadi anggota kelompok Maute saat diserang oleh tentara Filipina. Hal ini merupakan sebuah fakta yang cukup mengejutkan karena kelompok-kelompok separatis di Filipina Selatan biasanya memiliki kecenderungan untuk saling bermusuhan. Kelompokkelompok separatis di Filipina Selatan seringkali terlibat dalam friksi internal yang berujung kepada perpecahan organisasi. Perpecahan yang awalnya terjadi di tingkat elite akhirnya merembet ke pembentukan organisasi sempalan baru. Elite-elite yang bertikai selanjutnya membawa serta jaringan dan anak buahnya untuk turut menyempal. Di sisi lain, pemisahan secara organisasi tidak berujung kepada terputusnya jaringan kekeluargaan tersebut. Jaringan ini tetap dijaga khususnya dalam menghadapi situasi-situasi darurat seperti yang ditunjukkan oleh Kelompok Maute dalam sepak terjangnya di Mindanao.

Perekrutan calon jihadis dalam jaringan keluarga memiliki banyak keunggulan khususnya dalam memastikan supaya anggota baru tersebut mampu menerapkan loyalitas serta disiplin gerakan yang tinggi. Seorang anggota jihadis yang direkrut berdasarkan jaringan keluarga memiliki dua hal yang mampu "mengikat" loyalitas mereka: ikatan sebagai "keluarga" dan ikatan sebagai seorang "pejuang Islam". Kedua jenis ikatan ini berfungsi mulai dari ranah yang paling personal hingga ke ranah yang paling universal mengingat ikatan "keluarga" dapat mendorong seorang jihadis berjuang atas nama kehormatan keluarganya sekaligus melawan musuh-musuh agamanya.
Keluarga juga dapat berfungsi sebagai sarana untuk menginternalisasikan nilai-nilai radikal yang akhirnya membentuk seorang jihadis. Seorang jihadis biasanya memiliki sebuah pandangan akan dunia (worldview) yang menjadi latar belakang bagi perjuangannya. Keluarga selanjutnya dapat menjadi sarana yang tepat sekaligus paling efektif dalam mentransmisikan sekaligus menginternalisasikan pandangan-pandangan tersebut kepada anggota-anggota keluarga yang akan direkrut menjadi calon-calon jihadis.

Kecenderungan untuk menggunakan ikatan keluarga sebagai dasar perekrutan anggota jihadis bukanlah sesuatu yang baru di Filipina. Keluarga merupakan entitas yang sangat penting di dalam kehidupan sosial di negara ini. Ikatan keluarga yang sangat erat merupakan salah satu nilai dasar yang membentuk masyarakat Filipina. Di sisi lain, ikatan keluarga sejak dahulu telah digunakan sebagai modal dasar bagi orang-orang Filipina untuk menghadapi persaingan prestise sosial, ekonomi, maupun politik.

Ikatan keluarga di Filipina menjadi sarana untuk mengakumulasikan pengaruh (influence), kekayaan (wealth) serta jaringanjaringan politik (networking). Hal ini terlihat dari kemunculan berbagai dinasti-dinasti politik terkenal di negara ini seperti dinasti Aquino, dinasti Arroyo, dan dinasti Marcos. Keterlibatan keluarga Maute di dalam sepak terjang Kelompok Maute selanjutnya menjadi contoh lain dari pengaktifan jaringan-jaringan keluarga demi kepentingan tertentu, meskipun dengan tujuan yang jauh berbeda apabila dibandingkan dengan dinasti-dinasti politik lain.

Ikatan keluarga yang solid dan luas di Mindanao selanjutnya akan menjadi pekerjaan rumah terbesar bagi pemerintah Filipina. Mereka harus menemukan cara yang paling efektif untuk membendung dan menetralisir jaringan-jaringan keluarga yang diaktifkan oleh Kelompok Maute maupun kelompokkelompok separatis lainnya di Filipina Selatan. 
Penggunaan kekuatan militer semata tidak akan menyediakan solusi yang komprehensif bagi jaringan keluarga ini. Di sisi lain, penggunaan kekuatan militer dan metode kekerasan yang agresif justru dapat memperkuat solidaritas di dalam jaringanjaringan keluarga di Filipina Selatan yang seringkali melampaui sekat-sekat organisasi separatis di wilayah ini. Kekerasan yang represif justru akan memprovokasi sekaligus "membangunkan" jaringan-jaringan keluarga yang sebelumnya belum muncul. Hal ini tentu saja akan menambah eskalasi konflik di Filipina Selatan ke dalam skala yang mungkin tidak akan bisa diantisipasi oleh pemerintah Filipina maupun negara-negara di Asia Tenggara pada umumnya.

\section{Daftar Pustaka}

\section{Buku:}

Gerges, Fawaz A. A History of ISIS. New Jersey: Princeton University Press, 2016.

Gupta, Dipak. Who Are the Terrorist?

New York: Infobase

Publishing, 2006.

Martin, David, Ann Lane, dan Paul Schulte.

Terrorism, Security and the Power ofInformal Networks. Massachusetts: Mixed Sources Publishing, 2010.

Stepanova, Ekaterina. Terrorism in Asymmetrical Conflict: Ideological and Structural Aspects. New York: Oxford University Press, 2008.

\section{Jurnal:}

Adriano, Fermin dan Thomas Parks.

"The Contested

Corners of Asia: The

Case of Mindanao"

The Asia Foundation, 2013.

Kiefer, Thomas. "Modes of Social Action in Armed Combat: Affect, Tradition and Reason in Tausug". New Series. Vol. 5, No. 4 tahun 1970.

Macabuac-Ferolin, Maria Cecilia dan Norma V. Constantino. "Localizing Transformation: Addressing Clan Feuds in Mindanao Through PCIA". Journal of Peacebuilding

Development. Vol. 9. No.1 (2014).

$\begin{array}{llr}\text { Rijal, } & \text { Najamuddin } & \text { Khairur. } \\ & \text { "Eksistensi } & \text { dan } \\ \text { Perkembangan } & \text { ISIS: dari } \\ \text { Irak hingga } & \text { Indonesia", } \\ \text { Jurnal Ilmiah } & \text { Hubungan } \\ \text { Internasional. } & \text { Vol.13, } \\ \text { No.1 (September 2017) }\end{array}$

\section{Artikel Online:}

Abuza, Zachary. "Duterte and Prospects for Bangsamoro Peace"

[online]

http://www.newmandala.org/d uterte-prospects-bangsamoropeace/(diakses pada 30 Januari 2017)

Ansis, JC. "Butig Clashes: What We Know So Far"

[online]

http://cnnphilippines.com/regional/201 6/03/02/Butig-Lanao-del-Sur-clashesMaute-group.html (diakses pada 25 Januari 2017) 
Banlaoi, Rommel C. "Maute Group

Rise Family Terrorism"

[online]

https://www.rappler.com/tho

ught-leaders/173037-

mautgroup-rise-family-

terrorism (diakses pada 13

September 2017)

Cruz, Ian. "MILF: Group in Lanao not terrorists, disgruntled by peace deal's fate"

[online]

http://www.gmanetwork.com/news/ne ws/nation/557070/milf-group-in-lanaonot-terrorists-disgruntled-by-peacedeal-s-fate/story/ (diakses pada 25 Januari 2017)

Franco, Joseph. "Mindanao After the Philippines Presidential Elections"

[online]

http://www.newmandala.org/

mindanao-after-the-

philippines-presidential-

elections/(diakses pada 30

Januari 2017)

Gopalakrisnan, Raju dan Manuel Mogato. "The Mautes of The

Philippines: From Monied

Family to Islamic State"

[online]

http://news.abs-

cbn.com/focus/06/23/17/the-

mautes-of-the-philippines-

from monied-family-to-

islamic-state (diakses pada 13

September 2017)

Morales, Neil Jerome dan Tom Allard.

"The Maute Brothers: Southeast Asia's

Time Bomb"

[online]

http://www.reuters.com/articl

e/us-philippines-militants-

maute-idUSKBN19302Q

(diakses pada 30 Januari

2017)
Prima Satya, Putu Agung Nara Indra.

"Terlalu Naif Kalau Tanpa Uang

Tebusan" (Wawancara dengan Dr.

Samsu Rizal Panggabean)

[online]

https://tirto.id/terlalu-naif-

kalau-tanpa-uang-tebusan-bliy

(diakses pada 7 Februari 2017)

Prima Satya, Putu Agung Nara Indra.

"Kelompok Maute: Waralaba Baru ISIS di Filipina"

[online]

https://tirto.id/kelompok-mautewaralaba-baru-isis-di-filipina-b593

(diakses pada 25 Januari 2017)

Tordecilla, Kamilla. "Military Offensives vs Maute Group Continues"

[online]

http://cnnphilippines.com/news/2016/1

$1 / 28$ /military-offensive-maute-

group.html (diakses pada 25 Januari 2017)

Zambrano, Chiara. "The Ties That

Bind Maute Group and MILF".

[online]

http://k2.abs-

cbnnews.com/focus/03/03/16/

the-ties-that-bind-milf-and-

maute-group(diakses pada 30

Januari 2017)

Zambrano, Chiara. "Attempts to Talk

Peace with The Maute Group

Underway"

[online]

http://news.abs-

cbn.com/news/12/05/16/atte

mpts-to-talk-peace-with-the-

maute-group-underway

(diakses pada 25 Januari

2017)

Zambrano, Chiara. "Rebel Leader, 2

Brothers Killed in Lanao

Clashes" 
200 Putu Agung Nara Indra Prima Satya Maute Group Dan Jaringan Keluarga Dalam Kelompok Islam Radikal Di Filipina Selatan

[online]

http://news.abs-

cbn.com/nation/regions/v1/02

/28/16/rebel-leader-2- brothers-killed-in-lanao-

clashes (diakses pada 25

Januari 2017) 